Economia e Sociedade, Campinas, Unicamp. IE. http://dx.doi.org/10.1590/1982-3533.2021v30nespart01

\title{
Soberania, desenvolvimento e sociedade *
}

\author{
Carlos Aguiar de Medeiros ** \\ Fernando Sarti ${ }^{\text {*** }}$
}

\begin{abstract}
Resumo
A partir da formulação de Wilson Cano (1999) discute-se a questão da soberania da política econômica no contexto das economias latino-americanas. Argumenta-se que em sua evolução histórica, a subordinação da política econômica às finanças internacionais foi o principal divisor de águas entre o período desenvolvimentista e o período que se afirmou após os anos 1970. Estas economias recuperaram parcialmente uma maior autonomia no novo milênio, mas a abandonam sobretudo pós 2015. Argumenta-se que este abandono se deu num contexto externo bastante distinto do que se passou nos anos 1980 e 1990, quando reversão era imposta por crises cambiais e deve ser explicado, no caso da economia brasileira, por razões políticas internas. O conflito distributivo e a desnacionalização contribuíram para o triunfo do neoliberalismo como estratégia de acumulação.
\end{abstract}

Palavras-chave: Cano, Wilson, 1937-2020, Industrialização, Desenvolvimentismo, Abertura financeira, Política econômica, Conflito distributivo, Desnacionalização, Neoliberalismo.

\begin{abstract}
Sovereignty, development and society

Based on Wilson Cano's (1999) formulation, we discuss the sovereignty of economic policy in the context of Latin American economies. It is argued that during its historical evolution, the subordination of economic policy to international finance was the main watershed between the developmental period and the period that was established after the 1970s. Latin American economies partially recovered greater autonomy in the new millennium but lost it largely after 2015. It is argued that this took place in an external context quite different from that of the 1980s and 1990s, when reversal was imposed by exchange rate crises and can be explained, in the case of the Brazilian economy, by domestic political reasons. Distributive conflict and denationalization contributed to the triumph of neoliberalism as a dominant accumulation strategy.
\end{abstract}

Keywords: Cano, Wilson, 1937-2020, Industrialization, Developmentalism, Financial opening, Economic policy, Distributive conflict, Denationalization, Neoliberalism.

JEL O11, O14, O16, O24, O25.

\section{Introdução}

A soberania da política econômica constitui um tema crucial que perpassa as análises e questões teóricas e políticas postas nos trabalhos de Wilson Cano sobre desenvolvimento econômico, particularmente em seu livro "Soberania e Política Econômica na América Latina" publicado em 1999. Sua hipótese central era a de que para alguns países da América Latina, em especial para o Brasil, houve no período de 1929 a 1979 um 'longo e excepcional grau de soberania nacional no exercício e no manejo da política econômica de "desenvolvimento" (Cano, 1999, p. 7). Ao longo deste período os governos destes países 'puderam e quiseram' explorar as ‘brechas e contradições'

\footnotetext{
${ }^{*}$ Artigo recebido em 31 de março de 2021e aprovado em 26 de abril de 2021.

** Professor do Instituto de Economia da Universidade Federal do Rio de Janeiro (IE-UFRJ), Rio de Janeiro, RJ, Brasil. E-mail: carlosaguiarde@gmail.com. ORCID: https://orcid.org/0000-0002-6023-631X.

${ }^{* * *}$ Professor do Instituto de Economia da Universidade Estadual de Campinas (IE-Unicamp), Campinas, SP, Brasil. E-mail: fersati64@gmail.com. ORCID: https://orcid.org/0000-0002-0281-1662.
} 
do contexto internacional, exercendo deste modo significativo grau de soberania sobre a política econômica. A partir de 1979, os EUA “impuseram o chamado 'Consenso de Washington', centrado na dominação pela finança internacional. Isso reduziu fortemente nossa soberania nacional" (Cano, 1999:8). Estas políticas resultaram na formação de novos grupos econômicos articulados com as finanças internacionais e uma nova tecnocracia substituindo a antiga tecnocracia, "esta nova tecnocracia não tem compromisso duradouro com o serviço público nem com o país e, muito menos, com o povo; não raro, fez de sua curta passagem pelo governo um meio eficaz de enriquecer rapidamente, vendendo seus serviços ao capital internacional" (p. 8).

O objetivo principal deste artigo é discutir no contexto atual da região e do país duas proposições que emergem da análise de Wilson Cano. A primeira é a de que a 'dependência financeira externa' isto é, a subordinação da política econômica às finanças internacionais, constitui o principal divisor de águas entre os dois períodos examinados por Cano e, consequentemente, sobre as condições materiais que determinam o maior ou menor grau de soberania da política econômica. Em condições de escassez de divisas, como ocorreu na maioria das economias do continente ao longo dos 1980s e 1990s, os governos submetem suas políticas econômicas aos interesses e às perspectivas dos países credores e dos detentores de ativos, seguindo políticas econômicas que contrariam estratégias do desenvolvimento das atividades produtivas que não geram divisas, ou que não requerem para a sua implantação, de uma política econômica desenvolvimentista. Wilson Cano não examinou neste livro o período posterior iniciado em 2003, um período marcado por crescimento com abundância de divisas e redução da restrição externa ao crescimento econômico. Efetivamente, por mais de uma década os países da América do Sul e o Brasil, em particular, recuperaram maior grau de autonomia no manejo de política econômica exatamente porque houve substancial queda na dependência financeira externa. Em artigo posterior sobre a economia brasileira, Cano (2010) argumentou que, a despeito de iniciativas positivas na política de rendas, as oportunidades para um desenvolvimento produtivo maior foram desperdiçadas pela adoção de uma política econômica herdada do período anterior. Ou seja, no caso do Brasil, a redução da dependência externa não teria alterado o regime de política econômica herdado do neoliberalismo que se afirmou nos anos 1990. Os anos posteriores colocam uma questão adicional não examinada por Cano, mas instigada por sua análise: a reversão das políticas expansionistas e distributivas ocorridas na região, e particularmente no Brasil a partir de 2015, se deu num contexto externo bastante distinto do que se passou nos anos 1980 e 1990, quando as crises cambiais ampliaram fortemente a influência dos credores externos e das instituições internacionais sobre a política econômica. Esta circunstância leva à segunda proposição deste ensaio. De forma geral, mas sobretudo no caso da economia brasileira, o abandono de políticas de desenvolvimento deve ser explicado por razões internas. Como Cano argumentou em seu livro, a autonomia da política econômica na América Latina entre 1929 e 1979 resultou não apenas de uma possibilidade, mas também de uma vontade das elites e da tecnocracia exercida pelos governos. $\mathrm{O}$ que a evolução das políticas econômicas praticadas na região sugere, sobretudo no Brasil a partir de 2015, é que a 'disciplina dos mercados' (expressão eufemística da subordinação da política econômica doméstica aos interesses dos investidores financeiros), antes uma força imposta a partir das crises externas, tornou-se uma iniciativa essencialmente autoimposta por decisões políticas internas. De um lado, a crise constituiu uma oportunidade para reconstituir as relações de poder entre o capital e trabalho e, de outro, para redefinir o papel do Estado em sua relação com os capitais 
privados, ambos numa perspectiva favorável aos mercados. Devido ao significativo processo de desnacionalização e articulação financeira, ocorrido a partir de 2010, argumentou-se que as políticas econômicas defendidas pelos investidores internacionais na configuração da política econômica doméstica historicamente associados às pressões de instituições e credores externos, foram internalizadas e assumidas pelos grupos econômicos nacionais e defendidas no plano político e ideológico pelas tecnocracias no poder.

Ao lado desta introdução, estes argumentos foram desenvolvidos em cinco seções. A seção "O Modelo Financeiro-exportador e o Nacional Desenvolvimentismo", discutiu as características do modelo de crescimento primário exportador e a afirmação do nacional-desenvolvimentismo. Em "Neoliberalismo como Estratégia de Acumulação na América Latina", examinou-se a dinâmica da dependência externa deste regime de acumulação. A seção seguinte, "Nacionalismo de Recursos Naturais e Keynesianismo Social", discutiu as características do regime de crescimento, que se afirmou na América do Sul no novo milênio. Na seção em "Conflito Distributivo e Desnacionalização na Economia Brasileira", discutiu-se a especificidade da crise brasileira e o processo de desnacionalização ocorrido nos anos mais recentes. As Notas Finais concluem este texto.

\section{O modelo 'financeiro-exportador" e o nacional desenvolvimentismo}

O 'modelo de desenvolvimento voltado para fora' foi, tal como discutido por Raul Prebisch (1949), e que se afirmou no continente Latino-americano da segunda metade do século XIX até a grande crise de 1929, a rigor, um modelo 'financeiro-exportador' (Medeiros, 2008). No modelo, a integração financeira das economias primário-exportadoras assumiu uma dimensão essencial, tanto para a configuração do complexo exportador quanto para a delimitação das políticas econômicas. Incapazes de emitir dívidas em sua própria moeda, o crescimento econômico puxado pelas exportações era sistematicamente interrompido por mudanças nas condições financeiras internacionais. Nesta estratégia de acumulação ou 'modelo de crescimento', essencialmente assentada no livre comércio e na estabilidade de preços (ancorado na taxa nominal de câmbio), o ciclo econômico era determinado externamente e a direção da política econômica era a de garantir a conversibilidade das frágeis moedas nacionais, através de endividamento e atração de fluxos financeiros externos. Como Prebisch havia observado sobre o ciclo econômico na Argentina, apenas a industrialização poderia diminuir esta vulnerabilidade externa e a dependência financeira. Ao longo deste período o projeto hegemônico, isto é, as relações mais gerais do Estado com a sociedade (Jessop, 1990) que se afirmou na América do Sul (sobretudo após a Guerra do Paraguai) reproduzia os valores oligárquicos, a exclusão social e a forte repressão aos movimentos populares em defesa dos interesses fundamentais dos proprietários das atividades exportadoras (terras e minas) e dos detentores de títulos financeiros.

Com a crise de 1929 e a 'escassez de divisas' (Prebisch, 1949) que lhe sucedeu, abriu-se no continente uma oportunidade histórica (Cano, 1999) para uma nova estratégia de acumulação, a industrialização por substituição de importações (ISI), analisada exaustivamente por Tavares (1972).

(1) Seguimos aqui a formulação de Jessop (1990) considerando que uma estratégia ou modelo de crescimento inclui várias dimensões extraeconômicas e ocorrem dentro de um contexto definido por projetos hegemônicos que estruturam as relações entre o Estado e a sociedade. Esta perspectiva é convergente com a abordagem das Estruturas Sociais de Acumulação, como em David Kotz (2015) e incorpora diversos aspectos do estruturalismo latino-americano (Rodriguez, 2009). 
Esta estratégia, iniciada após moratórias da dívida externa e um afastamento ou desintegração financeira internacional, favorecendo essencialmente a indústria nacional em ascensão, só foi implementada de forma consistente naqueles países através do 'nacional-desenvolvimentismo', isto é, de um projeto hegemônico assentado no nacionalismo e no desenvolvimentismo. Tal como na Argentina de Juan Domingo Perón, no Brasil de Getúlio Vargas, no México de Lázaro Cárdenas, foram criadas novas burocracias e um novo poder político central, racionalizando os interesses dos capitais industriais domésticos voltados essencialmente à expansão dos mercados internos. Esta estratégia de acumulação, em que o protecionismo e políticas macroeconômicas expansivas acabaram por se impor (viabilizando as maiores taxas de crescimento da região), tornou-se cada vez mais complexo à medida em que a substituição de importações incluía importantes segmentos da indústria pesada. A internalização destes novos blocos de capitais e da infraestrutura energética e de transportes requereu uma ampla expansão de capital estatal e bancos públicos.

Este foi o período de forte expansão do PIB per capita das economias latino-americanas e de convergência em relação à economia dos EUA (Gráficos 1 e 2). No caso brasileiro, o PIB per capita relativo (a preços de 2011) saltou de 12,3\% em 1929 para 27,9\% em 1980, o que representou uma taxa de crescimento de mais de $120 \%$. No caso do México, embora o crescimento tenha sido menor, até porque partiu de uma base maior, o PIB per capita relativo se incrementou de 23,6\% para 33,5\% no mesmo período, atingindo o patamar histórico da série ao longo do século XX e nas primeiras duas décadas do século XXI.

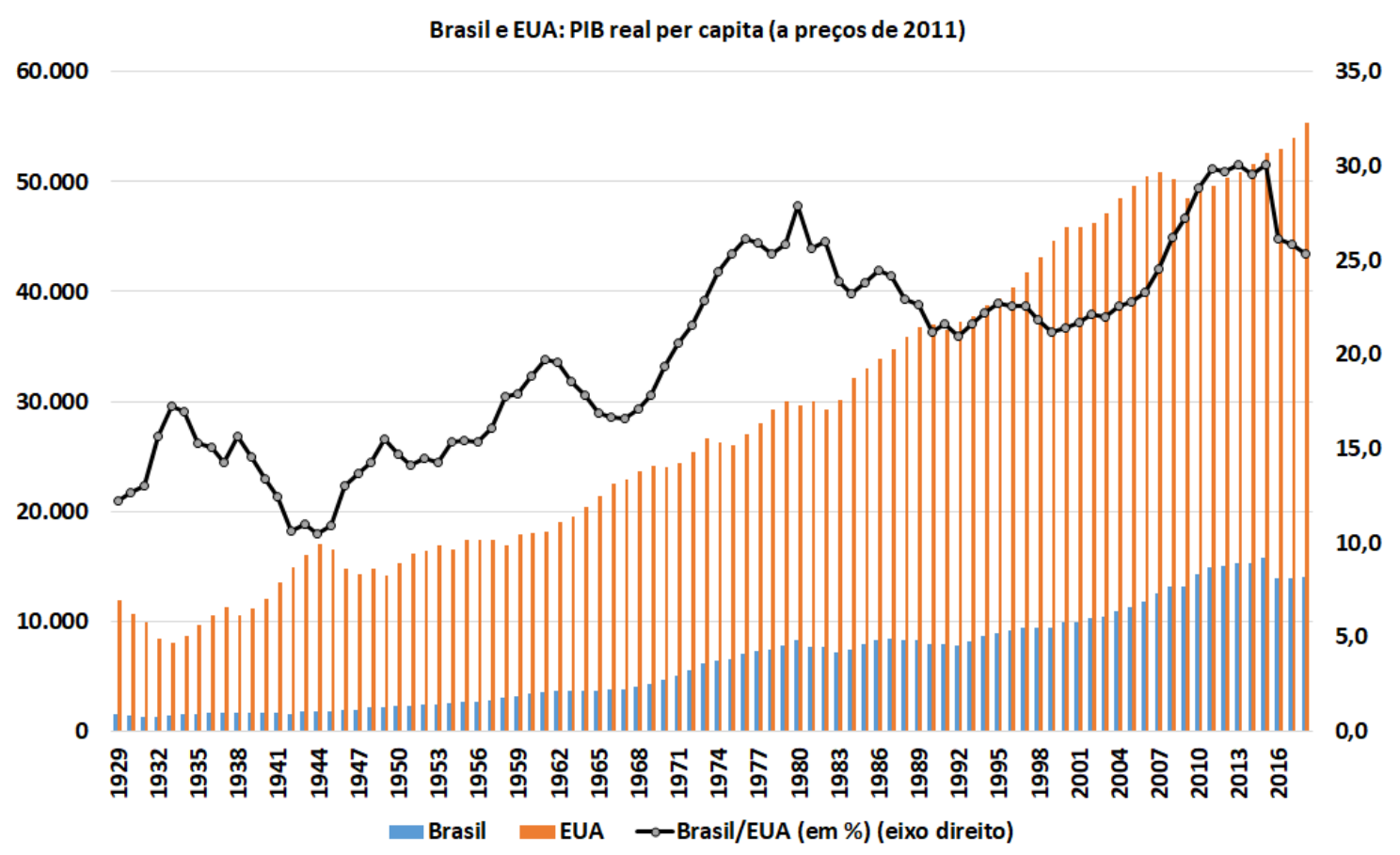

Fonte: Maddison Project Database - MPD (2020). 
Gráfico 2

Evolução do PIB per capita relativo do México 1929-2018 (EUA base = 100)

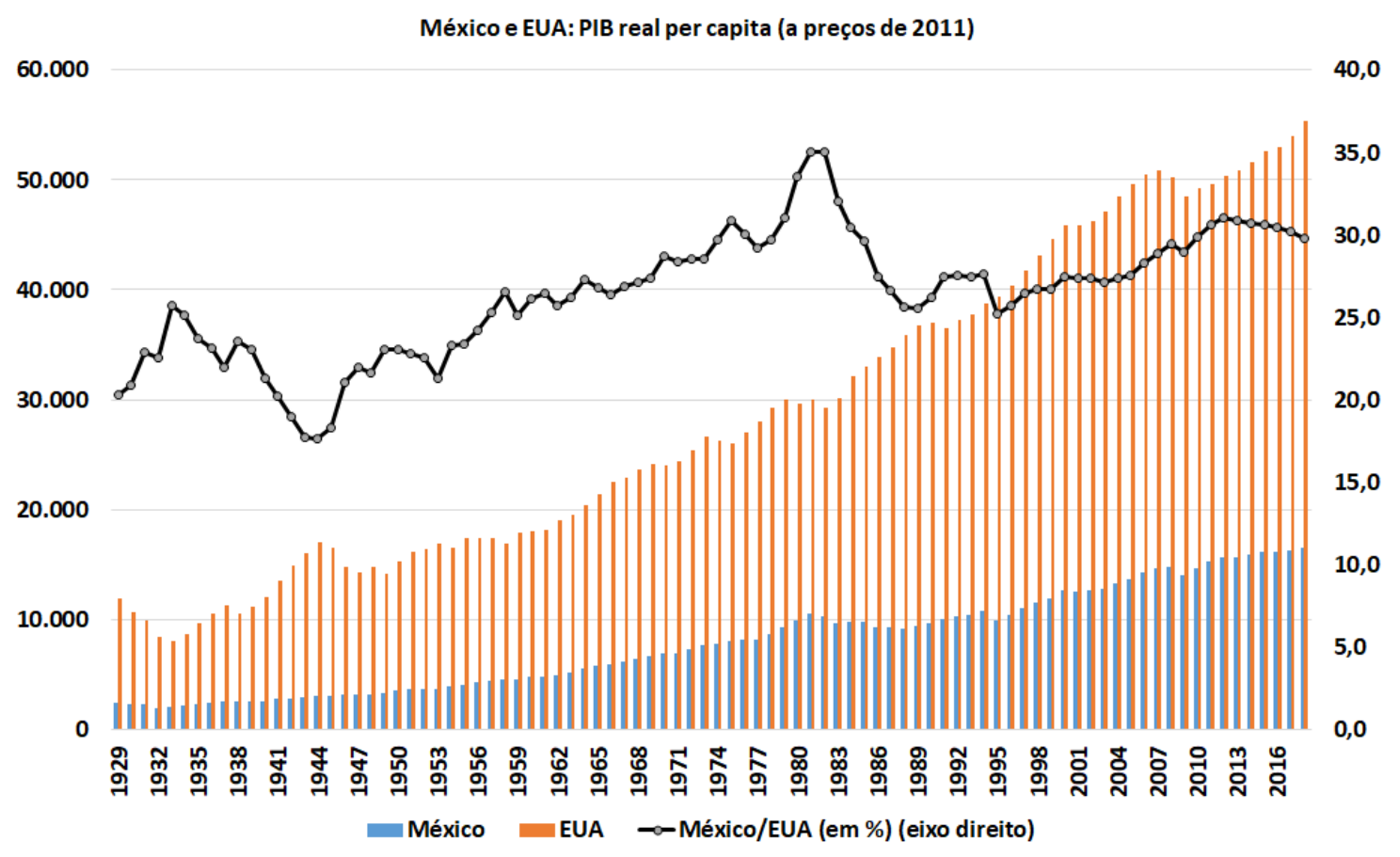

Fonte: Maddison Project Database - MPD (2020).

De forma distinta ao que se passou no Sudeste Asiático, nos anos 1950 e 1960, importantes blocos de empresas transnacionais (ET) se deslocaram para as economias maiores do continente configurando uma estratégia de acumulação com uma forte associação entre o capital estrangeiro e os capitais nacionais, em que o gasto do governo, os investimentos em infraestrutura e os investimentos das empresas estatais assumiram liderança e direção no processo do desenvolvimento (Medeiros; Sarti, 2020). Esta estratégia de acumulação de capital liderada pelo Estado soldava diversos interesses 'econômico-corporativos' na medida em que a escassez de divisas tornava o protecionismo, as taxas reais de câmbio desvalorizadas e a expansão do mercado interno o leito comum de interesses tanto dos capitais internacionais quanto dos capitais internos. Com exceção da Venezuela, em que a abundância de petróleo e a inexistência de um Estado desenvolvimentista inibiu o desenvolvimento de atividades industriais, nos demais países, em particular nas maiores economias, houve substancial diversificação produtiva, ainda que voltada principalmente ao mercado interno. Investimento público, crédito subsidiado e a expansão do mercado interno (ainda que houvesse uma grande concentração de renda) viabilizavam a expansão dos investimentos do conjunto de setores. $\mathrm{O}$ conflito entre as distintas frações de capital e os conflitos distributivos entre capital e trabalho só se manifestavam de forma mais aguda nos períodos marcados por forte restrição de divisas e sobretudo naqueles países que, como a Argentina, contavam com uma classe trabalhadora mais homogênea e organizada.

Com efeito, se no projeto hegemônico que se afirmou na Europa do pós-guerra com a expansão dos Estados Keynesianos de Bem-Estar, os interesses da classe trabalhadora organizada 
estavam incluídos na estratégia de acumulação regulada que se afirmou, estes interesses encontravam contradições muito maiores na América Latina. Como sublinhado por O’Donnell (1977), na Argentina, a estratégia de acumulação que correspondia aos interesses tanto da indústria nacional quanto dos trabalhadores era sistematicamente interrompida por crises de balanço de pagamentos (BP), dando origem a uma política econômica (desvalorização e contração fiscal) favorável aos setores agrário-exportadores e grupos internacionalizados. Esta política, entretanto, levava a forte recessão, tornando-se insustentável. Na Argentina este 'pêndulo' só foi parcialmente suspenso pelo golpe militar de 1976, que jogou para baixo os salários reais e o emprego industrial, enterrando, antes mesmo da crise de balanço de pagamentos dos anos 1980, a estratégia de acumulação seguida, bem como o projeto hegemônico que lhe conferia consistência. Por razões semelhantes e por fatores geopolíticos decorrentes do conflito sistêmico entre os EUA e a URSS, esta transformação também se deu no Chile e no Uruguai.

A evolução no Brasil foi distinta. Embora o golpe de 1964 tenha afastado os interesses da classe trabalhadora organizada do projeto nacional desenvolvimentista, a estratégia de acumulação e o projeto nacional desenvolvimentista seguiram a direção assumida na década anterior, com os salários reais absorvendo a elevação moderada dos preços que seguiam às minidesvalorizações cambiais. Houve aprofundamento da industrialização sob a liderança do Estado através de agências de fomento ao desenvolvimento produtivo, novas empresas estatais e forte expansão do investimento público. Uma direção convergente, ainda que menos diversificada, também se afirmou no México.

O nacional desenvolvimentismo dos anos 1970 se deu num contexto externo totalmente distinto das décadas anteriores. Devido à explosão dos preços do petróleo, queda das taxas de juros internacionais, desregulação financeira e mudanças na legislação americana sobre a 'imunidade soberana' houve uma forte expansão de empréstimos dos bancos internacionais e excesso de endividamento dos países periféricos, particularmente na América Latina. Esta circunstância externa viabilizou o prosseguimento da estratégia de acumulação anterior só que agora com crescente endividamento externo. Nos países que já haviam abandonado o nacional desenvolvimentismo (como no Cone Sul), o endividamento foi usado apenas para estabilizar a taxa nominal de câmbio e viabilizar o maior crescimento do produto e das importações. No Brasil ele foi usado para implementar o II Plano Nacional de Desenvolvimento. Entretanto, como observado em outro lugar (Medeiros, 1988), o endividamento elevado tem sua própria dinâmica quando o crescimento dos serviços da dívida excede o das exportações, nesse momento surge a necessidade de novos empréstimos e a farta disponibilidade desses gera um excesso de endividamento.

Essa trajetória de 'crescimento-com-endividamento' é interrompida na América Latina com a elevação pelo FED da taxa de juros em 1979 e com interrupção dos fluxos financeiros ocorrida a partir da moratória mexicana em 1982. Novamente a escassez aguda de divisas se impõe no continente e após sucessivas desvalorizações cambiais e transferências externas (oficiais e não registradas) se interrompe a estratégia de acumulação previamente seguida na região. A dependência financeira externa decorrente agora do elevado endividamento deslocou o 'controle nacional dos centros de decisão’ (Furtado, 1982) para os EUA e organismos como o FMI. Esta mudança nas relações de poder, tema explorado por Cano (1999), levou não apenas a uma mudança provisória na direção da política econômica, mas à crise do Estado nacional-desenvolvimentista, que correspondia à prévia estratégia de acumulação. 


\section{Neoliberalismo como estratégia de acumulação na América Latina}

A crise de balanço de pagamentos ocorrida na América Latina nos anos 1980 foi um divisor de águas entre as estratégias de acumulação e os projetos hegemônicos anteriores e os que se afirmaram a partir desta década ${ }^{2}$. A particularidade brasileira foi que a crise da dívida externa dos anos 1980 se deu simultaneamente com a redemocratização e adoção de uma nova Constituição, que continha uma avançada carta social (Medeiros, 2017). Entretanto, no Brasil, como no conjunto da América Latina, a crise de balanço de pagamentos e de fuga de capitais só foi interrompida pelo ingresso de capitais externos, viabilizados pelo plano Brady de reestruturação das dívidas, e pelas inovações financeiras, que abarcavam a securitização e o envolvimento dos fundos de pensão dos EUA na compra de títulos das economias periféricas (Medeiros, 2008). A renegociação da dívida e o ingresso de capitais aumentaram essencialmente as condicionalidades impostas pelos EUA, através do FMI, consubstanciadas num conjunto de reformas popularizadas como as reformas do 'Consenso de Washington'.

O novo ciclo de endividamento e aumento de ingresso de fluxos financeiros, base para a estabilização dos preços na região, foi precedido pelo desmantelamento dos mecanismos de controle dos fluxos de capitais, ampla abertura comercial e leilões de privatizações das empresas públicas. Estas transformações buscaram a implementação de uma nova estratégia de acumulação neoliberal ou "integracionista" (Amsden, 2007), baseada numa maior integração comercial e financeira com as economias centrais, em particular com os EUA. Nessa estratégia 'passiva e subordinada' (Cano, 1999) os 'technopols', o Banco Central e o Tesouro assumiram maior poder do Estado, subordinando as demais burocracias e técnicos da estrutura pública que exerciam funções importantes no planejamento econômico. A prioridade central era a implementação de políticas macroeconômicas assentadas na ancoragem dos preços na taxa nominal de câmbio, em defesa dos interesses econômicos corporativos que se fortaleceram no período: dos bancos, das empresas com elevada corrente de comércio e dos donos dos ativos dolarizados. $\mathrm{O}$ caso paradigmático aqui foi o da Argentina. $\mathrm{O}$ peronista Carlos Menem, eleito em 1989 com um programa nacionalista e distributivista, adotou nos anos seguintes um radical programa de estabilização, assentado na conversibilidade total do peso a uma cotação fixa com o dólar e em massiva privatização (Campello, 2015).

A política de estabilização baseada na taxa de câmbio nominal afetava desigualmente os setores econômicos. Com efeito, enquanto as empresas nacionais expostas à concorrência internacional demandam uma taxa real de câmbio (TRC) depreciada (como a que prevaleceu no período da industrialização por substituição de importações), os atores altamente integrados no comércio, investimento e nas finanças internacionais, desejam uma taxa nominal de câmbio estável

(2) Entende-se aqui por estratégia neoliberal de acumulação um conjunto de políticas iniciadas nos EUA e Inglaterra nos anos 1980 e generalizado nos anos 1990 para a maioria dos países como a renúncia ao Keynesianismo, diminuição da proteção social e ampliação dos mercados através da privatização e desregulação dos mercados (Kotz, 2015). Estas políticas justificadas no plano retórico como promotoras de melhor alocação de recursos e aumento de produtividade ampliaram de forma significativa o poder das grandes empresas e do sistema financeiro privado nacional e internacional sobre a política econômica e do capital sobre o trabalho. Esta estratégia diferenciase da prevalecente no capitalismo regulado por engendrar nas economias industrializadas uma trajetória de baixo crescimento e redução dos custos salariais (através da terciarização e subcontratação do trabalho). Nas economias periféricas estas transformações resultaram adicionalmente em aumento das importações (derivadas da abertura externa e desmontagem das políticas industriais), aumento dos fluxos de capitais (decorrente da abertura da conta financeira) e do endividamento tanto do setor privado quanto do setor público. 
(preferencialmente fixa) $^{3}$ (Frieden, 2015). Essa preferência é também a das empresas e dos estados nacionais endividados em dólares ${ }^{4}$. A elevação da taxa nominal de juros, visando a atração de fluxos financeiros, ao lado de sucessivas rodadas de privatização, foram as estratégias seguidas, que levaram a ciclos curtos marcados por valorização da TRC e seguidos por grandes desvalorizações, precedidas por massivas fugas de capitais.

A volatilidade dos fluxos financeiros e a fragilidade dos balanços de pagamentos, expressa no elevado peso dos passivos de curto prazo em relação às reservas, sistematicamente ameaçadas por fugas de capitais, tornaram a política econômica subordinada ao apoio e às prescrições do FMI, ao mesmo tempo em que ampliaram o poder econômico e político dos grupos dolarizados e internacionalizados. A desnacionalização da riqueza financeira e produtiva ocorreu de forma significativa e generalizada entre as principais economias da região como Argentina, Brasil e México. A vulnerabilidade externa na América do Sul chegou ao seu ponto máximo entre 1998-2002 e, em consequência, as políticas econômicas mantiveram-se submetidas à 'disciplina dos mercados', imposta pelos detentores de ativos dolarizados, através de seus movimentos especulativos viabilizados pela abertura financeira. Como parte substantiva desses passivos era de dívidas soberanas, as desvalorizações resultantes das crises cambiais, como as que ocorreram nesta 'mini década', aumentaram em termos reais a dívida dos Estados. O endividamento das empresas em dólares aumentava também o risco corporativo financeiro das desvalorizações.

São dois pontos centrais aqui que merecem ser destacados. Em primeiro lugar, com o acúmulo de ativos de curto prazo em relação às reservas, persistiu nos anos 1990 a "perda da soberania nacional no manejo da política econômica" (Cano, 1999) em que pese à mudança de sua composição e instrumentos, a política econômica foi reduzida à obtenção da "confiança dos investidores" e do aval do FMI, através de redução do prêmio de risco da dívida pública. Houve, porém, uma diferença importante: A ‘alienação dos centros nacionais de decisão' (Furtado, 1982) não se resumia a uma perda da soberania da nação frente à nação credora como os EUA, mas também a uma mudança na estrutura patrimonial do capitalismo nacional, uma vez que amplos blocos de capitais nacionais (privados e estatais) se desnacionalizaram e uma parcela importante da riqueza nacional tornou-se dolarizada e financeiramente integrada ${ }^{5}$. Nesse aspecto a grande diferença entre o México e os demais

(3) "Exposure to exchange rate volatility usually depends on involvement in international trade, finance, and investment. An enterprise that relies heavily on earnings from exports or foreign production, or is a substantial user of imported inputs or capital, can be hard hit by exchange rate fluctuations. Multinational corporations with facilities in several currency areas can have their business disrupted by unexpected exchange rate movements. In addition, investment planning can be hampered by uncertainty about the exchange rate. If foreign labor costs in a host country, measured in the home currency, rise substantially solely because the exchange rate moves, it can be costly for a multinational firm" (Frieden, 2015, p. 38).

(4) “... those with substantial foreign-currency debts can be expected to oppose a depreciation. All else being equal, $\bullet$ the larger a firm's net foreign-currency liabilities, the weaker its support for a relatively lower (more depreciated) exchange rate" (Frieden, 2015, p. 44).

(5) Como observou Arturo Guillén sobre o Consenso de Washington "El Consenso no consistió meramente en un decálogo de política económica impulsado desde Washington, con la colaboración del FMI y el Banco Mundial, ni reflejaba únicamente una convergencia de ideas neoliberales, sino que expresaba, ante todo, un compromiso político, un entramado de intereses, entre el capital monopolista-financiero globalizado del centro hegemónico estadounidense y las élites internas de América Latina. Estas buscaban con su inserción en la globalización una salida de la crisis y un nuevo campo de acumulación para sus capitales. Durante la etapa del ajuste ortodoxo de la década de 1980 se habían consolidado en los gobiernos latinoamericanos, sobre todo en el área financiera, un vasto número de cuadros neoliberales educados en las universidades estadounidenses del establishment (Chicago, Yale y Harvard) dispuestos a aplicar religiosamente las 'verdades' del nuevo decálogo neoliberal' (Guillén, 2021, p. 25). 
países latino-americanos é que no México, desde o tratado de livre comércio com os EUA e Canadá, a estratégia de crescimento esteve baseada na exportação de manufaturas intensivas em trabalho com componentes importados, voltada ao mercado americano e exercida em boa parte por firmas transnacionais ou mexicanas associadas. Mas independente da maior ou menor importância atribuída à exportação de manufaturas, a política econômica ortodoxa foi elemento comum, aproximando diversos blocos de capital. No Brasil, em que o mercado interno seguiu dominante como variável de demanda, a política econômica ortodoxa, como a que se afirmou no final da década, assentada no tripé formado por metas de inflação, superavit primário e câmbio flutuante, era não apenas a política defendida pelos organismos internacionais, mas também a política defendida por esses blocos de interesses e pela nova tecnocracia. Isto é, em relação à política econômica houve claramente uma internalização da dependência externa ${ }^{6}$.

O segundo ponto, que decorre parcialmente dessa transformação, é que essa estratégia de acumulação se deu com a construção pelo Estado de um novo projeto político hegemônico: O neoliberalismo (liderado por partidos novos como foi o caso do PSDB sob a liderança de Fernando Henrique Cardoso no Brasil ou por alas dos partidos tradicionais, como o justicialista Carlos Menem na Argentina ou Carlos Salinas do PRI mexicano ${ }^{7}$ ) não só distinto, mas rival ao nacional desenvolvimentismo. A estratégia de acumulação neoliberal assentada na liberalização, privatização e abertura financeira torna a fronteira de valorização do capital produtivo e financeiro muito porosa, fundindo os interesses entre essas órbitas ${ }^{8}$. Essas transformações e mudanças ocorridas na riqueza privada reduziram o comprometimento dos capitais privados com a estratégia de acumulação anterior assentada na proteção ao mercado interno e na liderança do Estado através de investimentos públicos" (Medeiros, 2017, p. 8). No caso brasileiro, diferentemente do ocorrido na Argentina e no México ${ }^{9}$, a

(6) No Brasil, como nos demais países da América do Sul nos anos 1990, o acesso à moeda externa por meio de uma política econômica voltada para conquistar a confiança do credor externo e do investidor financeiro foi a base essencial para as reformas neoliberais. Em consequência da liberalização financeira e comercial ocorrida ao longo dos anos 1990, as frações de capital internacionalizadas (formadas por grandes empresas em atividades financeiras e não financeiras com capital estrangeiro ou associado localizado na produção de manufaturados, exportação e agronegócio) ampliaram substancialmente seu poder sobre as políticas econômicas do Estado.

(7) No caso do México, a análise de David Morton sobre o triunfo do neoliberalismo é bastante didática: “... the crisis arose as a result of a conjunction of factors that also included the rise of technocrats - under way throughout the 1970s - which led to the ascendancy of the accumulation strategy of neoliberalism. ... a crucial issue at this time was the institutional career paths of the elite, which began to alter, so that ministries associated with banking and finance planning provided the career experience likely to lead to the upper echelons of government. What eventually unfolded in Mexico were specific transnational fractions of capital that would come to fuse the concerns of state managers, sectors of the business elite, large conglomerates tied to the export sector such as the maquila (in-bond) strategy of export-led industrialization" (Morton, 2007, p. 170).

(8) A leitura contemporânea descreve esse processo como financeirização, e a estratégia de acumulação como 'capitalismo financeiramente dominado' (Hein, 2013). Dentro desta perspectiva, Kaltenbrunner e Painceira (2020) discutiram as implicações da integração financeira subordinada na América Latina e Guillén (2021) examinou no caso do México o que descreve como 'regime de acumulação dominado pelas finanças'. Do nosso ponto de vista, a estratégia de acumulação neoliberal retém as características associadas à financeirização que decorrem da abertura da conta de capitais e desregulação financeira.

(9) No caso do México, o Tratado de Livre Comércio com os EUA e o Canadá foi o coroamento deste processo. "El TLCAN fue la joya de la corona de la reforma neoliberal. Se trató de un acuerdo entre gobiernos y grupos empresariales oligopólicos que veían en la integración una palanca importante para ampliar sus mercados y zonas de operación e influencia, así como para maximizar sus beneficios. En lo fundamental, fue impulsado por los grupos y empresas más globalizados del capital monopolista-financiero de los Estados Unidos, así como por los grupos y empresas más poderosos del Canadá y México. Las ETN estadounidenses más globalizadas veían en el TLCAN un instrumento para elevar sus niveles de competitividad en relación con otras regiones del mundo (Europa y Asia, principalmente), mediante el aprovechamiento de los bajos salarios y las normas ambientales laxas existentes en México. Las grandes empresas canadienses y mexicanas, por su parte, buscaban, mediante la apertura y el TLCAN, modificar sus estrategias y reconvertir sus empresas hacia el 
desmontagem do nacional-desenvolvimentismo e a estratégia de acumulação neoliberal não foi um projeto integralmente completado nesta década e só de fato irá acontecer anos mais tarde, a partir de $2015^{10}$.

De toda forma, a despeito da diversidade das experiências nacionais, diferentemente do que se passou no Sudeste da Ásia, não houve na América Latina maiores resistências 'econômicocorporativas' à adoção de uma estratégia de acumulação assentada essencialmente na abertura comercial, absorção de fluxos de IDE e compra de tecnologia. Essas estratégias, entendidas e defendidas como condição necessária e suficiente para a modernização produtiva e o aumento de produtividade, abdicaram e mesmo demonizaram o papel indutor exercido, previamente, pela política industrial e pela política de investimento do Estado. Essa resistência, entretanto, ocorreu nas classes populares. "Que se vão todos", proclamava o movimento popular na Argentina em 1992 contra as políticas econômicas monetaristas e os políticos que as implementaram.

\section{Nacionalismo de recursos naturais, e keynesianismo social}

O risco da dívida soberana, da fuga de capitais e do colapso do câmbio na virada da década dos 1990 constituía o principal temor e obstáculo para a retomada do crescimento e para uma nova política econômica, que reduzisse o desemprego e o conflito social. A eleição na Venezuela de Hugo Chaves em 1988 inaugurou uma nova direção nas estratégias e projetos nacionais na região, popularmente referida como 'onda rosa', mas essa nova direção só se afirmou tanto na Venezuela como nos demais países da região a partir das mudanças ocorridas nas condições financeiras internacionais a partir de 2002.

No Brasil, visando aplacar os ânimos e especulação dos investidores internacionais, Luís Ignácio Lula da Silva do PT divulgou na véspera de sua eleição em 2002 uma 'Carta aos Brasileiros' (apelidada de 'carta para agradar os banqueiros', Campello, 2015), anunciando a manutenção do regime macroeconômico (regime de metas, superavit primário, câmbio flutuante) e dos contratos, o que se constituiu em amplo desvio da agenda reformista difundida em sua campanha política. No ano seguinte o peronista Nestor Kirchner chegou ao poder na Argentina logo após um vasto movimento

\footnotetext{
mercado exterior para insertarse en una economía mundial crecientemente globalizada. Para el Gobierno de los Estados Unidos se trataba, además, de llevar a la práctica un conjunto de reglas para operar las inversiones extranjeras con una libertad irrestricta, así como un conjunto de prerrogativas: propiedad intelectual, tratamiento nacional a los inversores extranjeros, eliminación de normas de comportamiento, entre otros), que este país ha impulsado en diversos foros multilaterales y acuerdos, y que se tratan de aplicar en escala mundial. Pero quizás el objetivo estratégico más importante del TLCAN tanto del lado estadounidense como del mexicano era que con su firma se convertían en ley los elementos constitutivos de las políticas neoliberales, lo que aseguraba su irreversibilidad y cerraba el paso a cualquier tentativa populista ulterior" (Guillén, 2021, p. 27).

(10) “... the structural changes towards a neoliberal order of the 1990s did not destroyed neither all the developmentalists institutions inherited from the developmentalist period nor the social advances established by the new constitution. There were important changes, for sure. Some services were privatized, like telephone services and, partially, electricity, as well as large public firms (steel mills, the almost monopolist mining company, among others). The state oil company completed a large primary IPO in New York Stock Exchange, but was not privatized. Federal public banks either, although the local government banks were. Tariffs were reduced but not to a minimum level. Capital controls were lifted but the Central Bank kept a tight supervision over this market. On the social side, some minor changes on pensions occurred but the main tenets of the system were kept intact, like broad coverage and the guarantee that the lowest benefit paid could not be less than the minimum wage. The latter was also kept as a minimum remuneration for formal workers and its value, which was at a historically low point after the high inflation period, started to rise. The labor legislation was not significantly changed" (Bastos; Aidar, 2019, p. 28).
} 
popular e moratória da dívida externa. Nas duas economias os governos eleitos por coalisões de partidos de esquerda tomaram inicialmente distintas medidas. O Brasil seguiu uma linha ortodoxa semelhante à que vinha sendo praticada nos anos anteriores ${ }^{11} \mathrm{e}$ a Argentina, com maiores graus de liberdade decorrentes da moratória e do apoio popular, lançou um conjunto de políticas econômicas, visando obter maior taxa de crescimento e proteger a indústria nacional. Em ambos os países, os anos seguintes foram caracterizados por uma retomada significativa do crescimento e políticas econômicas que incluíram novas prioridades econômicas e sociais. A rigor, no Brasil, apenas no segundo mandato de Lula, iniciado em 2006, foram introduzidas políticas econômicas mais expansivas. Em ambos os países o prêmio de risco da dívida soberana caiu de forma substancial. O grande divisor de águas foi o aumento da liquidez externa decorrente da mudança no contexto internacional com a elevação da demanda e dos preços das commodities. No caso da Argentina, a moratória e posterior reestruturação da dívida diminuíram as transferências financeiras e, no caso brasileiro, contribuiu a entrada de amplo fluxo de capitais. Essa mudança no contexto internacional viabilizou uma onda de governos progressistas como Tabaré Vásquez no Uruguai (2004), Evo Morales na Bolívia (2005), Rafael Correa no Equador (2006) e Fernando Lugo no Paraguai (2008). A reeleição de Chávez em 2000 e posteriormente em 2006, Lula em 2006, a eleição de Cristina Kirchner em 2007 e de Dilma Rousseff em 2010 reforçaram este movimento de afastamento das políticas neoliberais ortodoxas.

A redução da dependência externa, através de substancial acúmulo de reservas e maior autonomia frente ao FMI, foi o denominador comum destas experiências, que de resto tiveram amplas diferenças internas, segundo as distintas estruturas econômicas e coalisões políticas ${ }^{12}$. A estratégia de acumulação, que começou a se afirmar na região, tinha como protagonistas as exportações de commodities, os investimentos, principalmente aqueles induzidos por essas exportações, os gastos do governo (sobretudo nas economias mineiras com as receitas públicas atreladas ao setor exportador) e o consumo das famílias, decorrente do crescimento dos salários e das transferências. Ainda que contassem com distintas estruturas políticas e movimentos sociais, essa evolução resultou numa redução da desigualdade da renda e aumento da parcela salarial no produto.

No caso do Brasil, essa estratégia se deu com o regime macroeconômico consolidado em 1999, com poucas alterações em relação à ortodoxia dos anos 1990. Essa estratégia também não foi rompida no Equador, que manteve uma dolarização completa da economia, em contraste com o que se passou na Argentina e na Venezuela, que se afastaram inteiramente do modelo de integração financeira anterior. Ainda assim, o maior protagonismo do Estado na administração do balanço de pagamentos e na indução da taxa e da direção do crescimento afirmou-se em quase todos os países

(11) Como observaram Bastos e Aidar (2019) sobre os governos do PT "President Lula was able to combine moderately expansionary fiscal policies with socially oriented transfers, higher growth and persistent high primary surplus. Therefore, the party could 'overcome' a neoliberal criticism that its 'leftism' was incompatible with 'fiscal responsibility'. The problem with this 'fortunate coincidence" was that, in political terms, the party became a 'hostage' of its own 'success', by never confronting, in political terms, the fiscal orthodoxy or balanced budget (in fact, primary surplus) dogma. When, the primary surplus started to progressively dwindle, the answer by president Rousseff's administration was not to try to explain to the society that it was the result of the economic slowdown, and the consequent fall of revenues, but to use accounting tricks, creative accounting, to hide the deterioration of the surplus. In fact these accounting practices were behind the impeachment process" (Bastos; Aidar, 2019, p. 17).

(12) "The so-called moderate, or market-oriented Left followed remarkably different strategies, sometimes barely distinct from its neoliberal opponents. Chile under the Socialist governments of Eduardo Lagos and Michele Bachelet, Brazil under Lula da Silva and Dilma Rousseff of the Workers' Party, and Uruguay governed by Tabaré Vázques and José Mujica of the Broad Front, all advanced redistributive policies, but only within the limits imposed by an orthodox macroeconomic agenda" (Campello, 2015, p. 66). 
da América do Sul, incorporando novas dimensões na estratégia de acumulação engendrada na década anterior. Os investimentos públicos passaram por forte crescimento ${ }^{13}$. Do ponto de vista do projeto hegemônico, a novidade que se afirmou na 'onda rosa' foi uma política mais ampla de inclusão social, através de transferências fiscais (com distintos graus de participação e envolvimento dos trabalhadores), e um maior controle nacional sobre os recursos naturais (tanto através de nacionalização de setores como na Argentina, Bolívia e Venezuela, quanto pela expansão das empresas estatais já existentes, caso do Brasil).

Esta nova direção de política econômica (e este novo projeto), entretanto, não foi acompanhada por políticas industriais abrangentes voltadas à diversificação produtiva, que permitissem deslocar o tipo de especialização exportadora assentada em recursos naturais. Algumas iniciativas foram introduzidas e, sobretudo, buscou-se uma nova regionalização indutora de uma maior articulação e expansão regional (como na Unasul), mas sem impactos significativos sobre a estrutura produtiva. Embora no caso brasileiro os investimentos tivessem crescido a uma taxa elevada entre 2003 e 2010, a estrutura produtiva que se afirmou nesta década era semelhante à que existia nos anos 1990. Tanto na Argentina quanto no Brasil, desde os anos 1990s a estrutura produtiva passou por uma "especialização regressiva" (Hiratuka; Sarti, 2015) com a perda de importantes elos da cadeia produtiva, engendrando, em consequência, uma elevada propensão a importar (Abeles; Cherkasky 2020) ${ }^{14}$. Com a queda dos termos de troca ocorrida logo após a crise de 2008 , e com a redução da demanda internacional, a balança de transações correntes mudou de sinal e consolidou-se um crescente déficit, financiado (com a exceção da Argentina e Venezuela) principalmente por massivos fluxos de IDE e de capitais de curto prazo. Estimulado pela política monetária praticada pelo FED, os fluxos de capitais de curto prazo para as economias emergentes foram massivos ${ }^{15} \mathrm{e}$, em particular, para o Brasil, que praticou elevadas taxas de juros reais. Ao lado deste fluxo de capitais, houve na última década uma grande expansão de IDE e do endividamento das empresas em dólares. Bancos comerciais e empresas de serviços financeiros lideraram a emissão de títulos em dólares, seguidos pelas atividades de energia, mineração, telecomunicação, setor imobiliário e indústria ${ }^{16}$.

Desse modo, embora a transferência líquida de recursos (ingresso líquido de capitais menos pagamento líquido de lucros e juros) tenha diminuído e, em muitos países, tenha se tornado negativa, não foi o crescimento deste déficit e acúmulo de passivos de curto prazo que, na segunda década do milênio, interromperam e mesmo levaram a uma abrupta reversão da estratégia de acumulação e do projeto hegemônico, que se afirmou no período. A manutenção de elevadas reservas vis-à-vis os passivos externos e o nível relativamente baixo da dívida externa do setor público mantiveram os prêmios de risco da dívida relativamente baixos e sob a vigência de regimes de câmbio flutuante não houve fugas massivas de capital. Os spreads dos títulos das economias latino-americanas tanto

(13) No caso brasileiro, o crescimento se deu entre 2006 e 2010 e, nos anos posteriores, durante o governo de Dilma Rousseff, houve uma queda, ver Serrano e Summa (2015).

(14) A formulação predominante sobre a experiência brasileira (Bresser-Pereira, 2016) atribui a ausência de mudança estrutural à valorização da taxa real de câmbio ocorrida no período de,0 2003-2010. Entretanto, o investimento em máquinas e equipamentos foi bastante mais elevado neste período do que na segunda década em que a taxa de câmbio real se desvalorizou. Para uma discussão destas conexões e literatura ver Serrano e Summa (2015).

(15) Incluindo novos investidores como os 'exchange-traded funds', e 'macro-hedge funds' (Kaltenbrunner; Painceira, 2020).

(16) Para uma análise quantitativa dos indicadores de endividamento, ver próxima seção. 
públicos quanto privados (EMBIG), depois de uma forte elevação em 2008, caíram substancialmente nos anos subsequentes. (ECLAC, 2020)

Uma diferença notável, em grande contraste com o que ocorreu nos anos 1990 (esta questão não rara passa despercebida na literatura estruturalista contemporânea ${ }^{17}$ ), é que com câmbio flutuante, largas reservas formadas com ingressos de capitais (decorrentes da intervenção do Banco Central, reduzindo o efeito destes fluxos sobre a taxa de câmbio), principalmente sob a forma de IDE e de compra de títulos denominados em moeda nacional, e não sob a forma de dívida soberana, os riscos da especulação recaem integralmente sobre o investidor e não sobre o regime cambial ${ }^{18}$. Desse modo, os fluxos financeiros de curto prazo ocorridos principalmente no Brasil, Chile e México, a partir de 2010, não resultaram na conhecida sequência de valorização-crise cambial-desvalorização, típica dos anos 1990.

Com a inexistência de uma crise cambial, a virada da política econômica deve ser explicada por fatores internos. O caso paradigmático aqui é do Brasil. Com efeito, a guinada na política econômica para 'agradar os banqueiros' ocorrida em 2015, logo após as eleições que sufragaram Dilma Rousseff para um segundo mandato, se deu num contexto totalmente distinto do que se passou em 2002, quando Lula assumiu o governo em meio a uma grande vulnerabilidade externa. Se em 2002 o nível de reservas brasileiras mal atingia os US\$50 bilhões, em 2015 as reservas totalizavam US $\$ 360$ bilhões, assegurando alta liquidez ao balanço de pagamentos do país, aferido pela relação entre e a dívida externa de curto prazo e as reservas ${ }^{19}$. Desse modo, a guinada deve ser explicada por decisões internas auto-infligidas ${ }^{20}$, que expressam tanto as ideias quanto os interesses que se formaram dentro e fora do governo.

A circunstância da Argentina foi distinta. Com efeito, a partir da moratória dos anos 2000, o país ficou à margem dos fluxos financeiros internacionais, em um momento de reversão do ciclo externo (e em particular a desaceleração do crescimento do Brasil, seu principal mercado para bens

(17) O artigo de Roberto Frenkel e Martin Rapetti (2012) constitui uma exceção desta perspectiva. Para eles, graças ao elevado nível de reservas, câmbio flutuante e baixo endividamento, a América Latina possuía condições externas muito superiores do que as que se afirmaram nos anos 1990. O problema do forte ingresso dos fluxos financeiros como o que começou a ocorrer a partir de 2010 era a sobrevalorização da TRC com impactos negativos sobre a lucratividade do setor industrial. Essa não foi, entretanto, a experiência brasileira após 2010. Depois de forte valorização entre 2003 e 2008 a TRC desvalorizou-se na segunda década do milênio em meio a forte ingresso de capitais graças à intervenção do Banco Central. (Serrano; Summa, 2015)

(18) "Interest payments have to be paid in foreign currency - typically US dollars - and since they are contractual obligations, they constitute a source of foreign currency outflow that is delinked from the business cycles. On the contrary, FDI dividends are largely obtained in domestic currency - making their value in foreign currency depend on the exchange rate - and are highly correlated to the business cycles. This implies that in the case of a capital inflow deceleration or reversal, the magnitude of FDI dividend payments tends to contract due to both the depreciation of the domestic currency and the deceleration or contraction of domestic economic activity" (Frenkel; Rapetti, 2012,p. 5).

(19) Sobre a experiência brasileira, Serrano e Summa (2015) observaram: "Given these external changes and the improvement in the management of its financial account in the current dirty floating exchange rate regime, Brazil has had no scarcity of foreign exchange since 2003, in spite of its large current account deficits. Accumulated foreign exchange international reserves reached a peak of USD\$375 billion by mid-2012 and have been oscillating around this level since then. This massive accumulation of foreign exchange reserves improved the indicators of external solvency and external liquidity" (2015, p. 806).

(20) "In the last two decades, the external conditions changed dramatically, relaxing the external constrain to most part of Latin American countries (with the exception of 2009 during the international crisis). Despite the 'comfortable' external conditions, the Brazilian short 'golden period' in the first decade of 2000 was suddenly interrupted4. Therefore, we call it a self-inflicted crisis" (Bastos; Aidar, 2019, p. 4). 
industriais), o que resultou numa a crise cambial. Devido ao câmbio flutuante, essa crise foi bem menos espetacular em relação à que ocorreu no final dos anos 1990, mas foi importante para a eleição de Mauricio Macri em 2015 e para a direção ortodoxa seguida na política econômica. Esta direção se espalhou no continente nos anos seguintes.

\section{Conflito distributivo e desnacionalização da economia brasileira}

Como no Brasil a ameaça, na segunda década do novo milênio, de uma crise cambial e financeira não exercia o mesmo poder sobre a política econômica, a virada da política econômica em 2015 e a vitória da agenda neoliberal requerem uma interpretação baseada nos fatores domésticos, decorrentes dos conflitos distributivos e dos interesses constituídos entre as diferentes frações de capital.

A clássica formulação de Michael Kalecki (1943) sobre o crescimento nas economias capitalistas $^{21}$ encontrou forte apoio nas discussões relativas à crise da 'Golden Age' no capitalismo central (Kotz, 2015) e pode ser considerada no contexto latino-americano e, particularmente, no Brasil. Com efeito, se historicamente as crises de balanço de pagamentos interrompiam ciclicamente o crescimento, impondo uma política de austeridade que visava angariar a 'confiança dos investidores' e reduzir as pressões salariais, nas novas circunstâncias externas este fator deixou de ocorrer. Ainda que tivesse havido uma desaceleração do crescimento do produto entre 2010 e 2014, o nível de emprego mantinha-se alto e os salários reais cresciam acima da produtividade, bem como os custos indiretos decorrentes das transferências sociais financiadas pelo governo e pelas empresas ${ }^{22}$. O conflito distributivo unificou diferentes frações do capital na defesa de uma política ortodoxa tendo por eixo a contração fiscal, a reforma trabalhista e previdenciária. Estas reformas foram radicalizadas e implementadas após o impeachment de Dilma Rousseff.

Mas a crise criou não apenas oportunidades para rever as relações de trabalho e mudar a distribuição a favor do capital, ela também consolidou uma nova direção para a política de desenvolvimento, ampliando a convergência dos interesses econômicos das elites para a implementação de uma estratégia de acumulação semelhante à que vigorou nos anos 1990 sob o 'Consenso de Washington' e assentada em privatizações e maior abertura externa. Com efeito, diferentemente do que se passou na Bolívia e na Venezuela, onde, tendo em vista a orientação socialista destes governos, os conflitos de classe elevaram-se, e mesmo na Argentina, onde a nacionalização e as intervenções do Estado foram na direção oposta à perspectiva neoliberal, no Brasil, os governos do PT contaram com o apoio das organizações empresariais, tanto da indústria

(21) A redução do desemprego e consequente aumento do poder de barganha dos assalariados (tanto no mercado de trabalho quanto na disciplina no chão de fábrica) acabava por suscitar na classe capitalista, argumentou Kalecki, uma reação às políticas expansionistas do governo e crescente pressão para adoção de 'finanças saudáveis' de forma a recompor maior poder de barganha dos empresários. Essa dinâmica de crescimento com conflito distributivo é influenciada por diversos fatores entre os quais a maior ou menor capacidade de organização dos trabalhadores e o ritmo do crescimento da produtividade.

(22) Essa interpretação Kaleckiana do ciclo político e do conflito distributivo foi amplamente discutido na evolução da 'breve Golden age' da economia brasileira em Serrano e Summa, (2018) A interpretação de Álvarez (2020) sobre a economia Argentina é também convergente com esta interpretação: "By following the Latin American Structuralism, the reconstruction stressed that it was the threat of the political order represented by the popular government and the participation of unions provoked the rejection of the capitalist class to the pattern of industrialized development and induced the reinforcement of the dependent character of the Argentine economy, as an obstacle to disciplining the labour movement" (Álvarez, 2020, p. 85). 
quanto dos bancos, satisfazendo distintos interesses corporativos e setoriais (Medeiros; Trebat, 2021). Desde os anos 1990, os processos de privatização, desnacionalização e dolarização solidarizaram distintos interesses setoriais em apoio à estratégia de acumulação. Nos anos 2000, em que pesem significativas mudanças distributivas e maior protagonismo do Estado e das empresas públicas, o processo de desnacionalização e fusão de capitais, sob a liderança das empresas transnacionais (ETNs), ganhou novo impulso, particularmente após 2010.

Com efeito, posteriormente à grande crise financeira internacional, o Brasil tornou-se um dos espaços privilegiados de expansão do capital estrangeiro. $\mathrm{O}$ incremento do fluxo de investimento direto para o país (IDP) foi superior ao observado no fluxo global. O valor acumulado de US\$682,1 bilhões no período 2010-2019 representou 4,3\% do valor global, duplicando a participação brasileira com relação ao período 2000-2009 (2,2\%) (Tabela 1). Segundo o Bacen, a posição (estoque) total do IDP $^{23}$ para um total de 17.326 empresas estrangeiras atuantes no país era de US\$ 874,0 bilhões em 2019, sendo US\$ 623,3 bilhões na modalidade de participação no capital e US\$ 250,7 bilhões na modalidade de empréstimos intercompanhia. Em contrapartida, a posição total do investimento direto no exterior (IDE) era de US\$ 416 bilhões, composto por US\$ 385 bilhões na modalidade de participação no capital e US\$ 31,5 bilhões em empréstimos entre companhias. Importante destacar que uma parcela significativa desse estoque de IDE está em paraísos fiscais e em "Serviços financeiros e atividades auxiliares e Holdings". Como apontam Hiratuka e Sarti (2021), essa concentração do IDE brasileiro indica que a estratégia predominante de internacionalização do capital brasileiro não está focada na exploração de atividades produtivas no exterior, mas sim em se posicionar em ativos financeiros de elevada liquidez e de natureza especulativa.

Tabela 1

Fluxo acumulado de Investimento Direto no País (IDP) e de Investimento Direto no Exterior 2000 a 2019 (em US\$ bilhões e participação)

\begin{tabular}{l|c|c|c|c|c|c}
\hline \multirow{2}{*}{ Investimento Externo } & $2000-2009$ & $2010-2019$ & $2000-2019$ & $2000-2009$ & $2010-2019$ & $2000-2019$ \\
\cline { 2 - 7 } & US\$ & US\$ & US\$ & em \% & em \% & em \% \\
\hline Investimento Direto no País (IDP) & 239,6 & 682,1 & 921,7 & 2,2 & 4,3 & 3,3 \\
\hline Investimento Direto no Exterior (IDE) & 60,7 & 21,6 & 82,4 & 0,5 & 0,1 & 0,3 \\
\hline
\end{tabular}

Fonte: Unctad.

A intensificação da internacionalização produtiva pode ser corroborada pelo indicador de estoque de IDP em relação ao PIB. Segundo dados da Unctad, a relação entre o estoque de IDP total e o PIB atingiu 35\% em 2019 no Brasil, contra 21\% em 2001 e 29\% em 2010, superando a relação média dos países emergentes industriais (23\% em 2019), mas ainda abaixo da média dos países industrializados (51\%). O México, outro importante receptor de investimento estrangeiro, ampliou de $17,2 \%$ para $49,7 \%$ a relação entre o estoque de IDP e o PIB entre 2000 e 2019, o que configura uma estrutura produtiva fortemente internacionalizada com elevada presença de capital estrangeiro.

(23) Segundo informa o Bacen, a posição é "valorada preferencialmente por valor de mercado e, na ausência deste, por patrimônio líquido”. Do total de 17.326 empresas estrangeiras em 2019, 15,7 mil foram valoradas pelo patrimônio líquido e 1,6 mil pelo valor de mercado. 
Tabela 2

Estoque de Investimento Direto no País em relação ao PIB (em \%)

\begin{tabular}{l|c|c|c}
\hline \multirow{2}{*}{ Investimento Direto no País (IDP) } & \multicolumn{3}{|c}{ Estoque de IDP no PIB } \\
\cline { 2 - 4 } & 2001 & 2010 & 2019 \\
\cline { 2 - 4 } & $(\%)$ & $(\%)$ & $(\%)$ \\
\hline Brasil & 21,0 & 29,0 & 35,3 \\
\hline China & 15,2 & 9,6 & 12,4 \\
\hline Coreia do Sul & 9,7 & 11,8 & 14,3 \\
\hline México & 21,1 & 36,8 & 49,7 \\
\hline Economias Industrializadas & 22,4 & 30,1 & 41,8 \\
\hline Economias Industriais Emergentes & 23,4 & 33,2 & 51,6 \\
\hline Mundo & 17,8 & 23,1 & 23,5 \\
\hline
\end{tabular}

Fonte. Unctad.

Importante observar, que os elevados fluxos de IDP no país permitiram, como observado anteriormente, financiar integralmente os déficits em conta corrente no período de 2000-2020, com exceção dos anos de 2013 e 2014, diferentemente do que ocorreu nos anos 1990, quando o financiamento do balanço de pagamentos contou com os especulativos e voláteis investimentos em carteira. No período 2000-2019, o déficit em conta corrente acumulado foi relativamente baixo, em função dos superávits obtidos nos anos de 2003 a 2007, atingindo US\$ 71,4 bilhões. Esse déficit foi financiado com sobras pelo fluxo de US\$262,7 bilhões de IDP. No período 2010-2019, embora o déficit acumulado em conta corrente tenha atingido o elevado montante de US\$ 606,3 bilhões, a intensificação do fluxo de IDP, que acumulou US\$ 795,6 bilhões, também permitiu financiar com tranquilidade o déficit em transação corrente.

Gráfico 3

Brasil: Evolução do Déficit em Transações Correntes e do Investimento Direto no País em relação ao PIB 1995-2020 $(\mathrm{em} \%)$

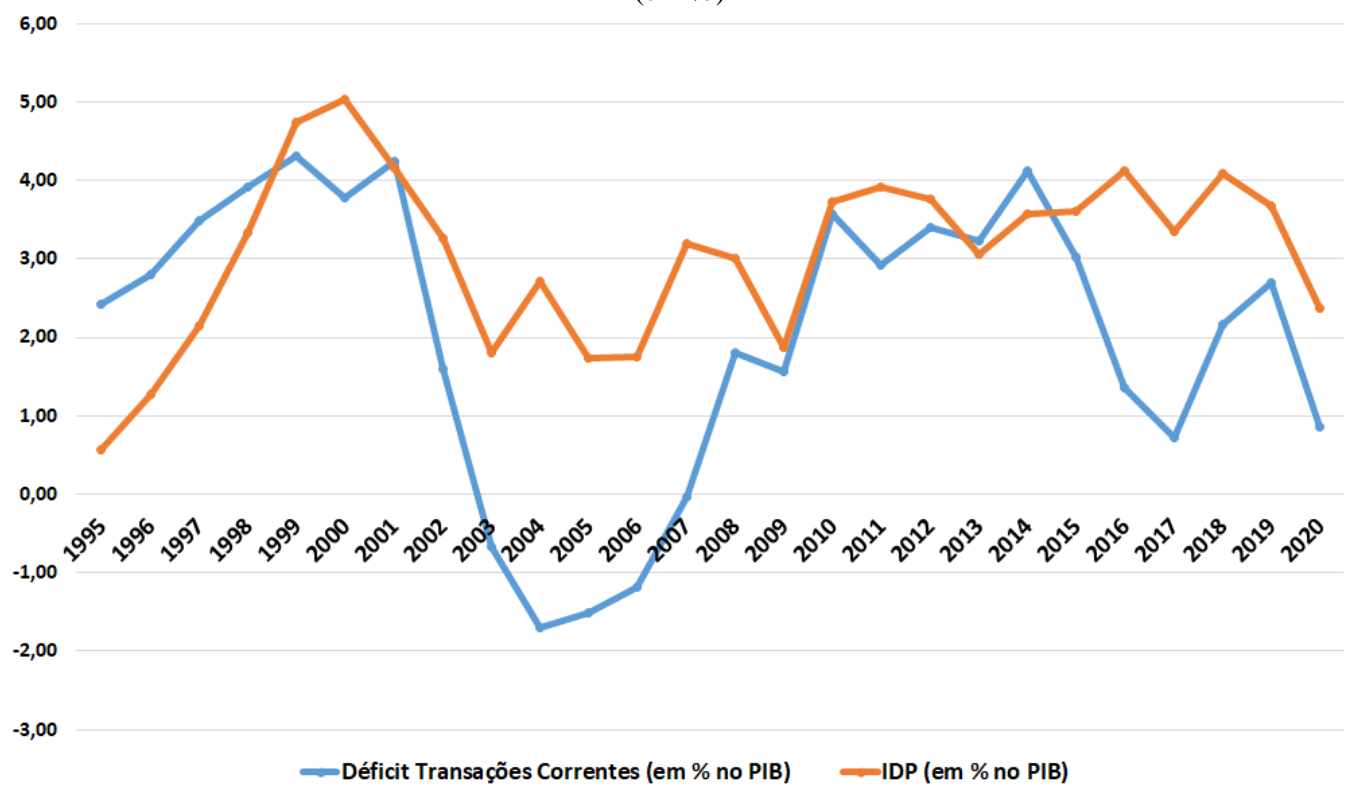

Fonte: Banco Central do Brasil (2020). 
$\mathrm{O}$ apetite do capital estrangeiro pelo mercado brasileiro tem promovido um intenso processo de desnacionalização, sobretudo através de operações de aquisições de empresas. A rigor, a expansão das operações de aquisições e fusões (A\&F) transfronteiriças se insere no âmbito das estratégias de internacionalização e acumulação das grandes corporações globais. As políticas "amigáveis" com relação ao capital externo no Brasil têm permitido transformar o país em um dos espaços preferenciais de entrada e de acumulação do capital estrangeiro.

Como analisado em Sarti e Laplane (2019, 2021) e Medeiros e Sarti (2020), a partir de dados da empresa de consultoria KPMG, as operações transfronteiriças ou cross-border (CB), operações que envolveram na aquisição e/ou na venda pelo menos uma empresa estrangeira, aumentaram a partir da crise internacional, puxadas pelas operações, em que empresas estrangeiras adquirem empresas domésticas no Brasil. De 2010 a 2019, essas operações totalizaram 2.732 transações, pouco mais que $60 \%$ do total das operações CB. Os trabalhos também analisaram os dados de aquisições e fusões divulgados pela Associação Brasileira das Entidades dos Mercados Financeiro e de Capitais (Anbima). No período 2009-2018, as operações de empresas estrangeiras adquirindo empresas nacionais atingiram a expressiva soma de US $\$ 781,8$ bilhões, quase $40 \%$ do valor total de operações anunciadas, a preços de 2018 , em um total de 310 operações.

Outro fator importante tem sido o crescente endividamento em dólar por parte das empresas não financeiras. Se, por um lado, a estratégia permite arbitrar o diferencial de taxa de juros interna e externa e a obtenção de ganhos financeiros especulativos, por outro, amplia o risco e a vulnerabilidade financeira das empresas em função dos impactos de uma desvalorização da taxa de câmbio sobre o estoque da dívida em dólar. A partir das informações do Banco Central do Brasil, considerando o crédito ampliado concedido ao setor não financeiro (empresas, famílias e governo), que abarca os empréstimos e financiamentos, títulos de dívida e dívida externa, é possível observar a crescente participação da dívida externa no total de crédito concedido, que saltou de 16,2\% em início de 2013 para 20,3\% em final de 2019. Esse crescimento da relação dívida externa e crédito total concedido deveu-se sobretudo ao endividamento externo das empresas. A participação da dívida externa no total de créditos concedidos às empresas saltou de 23,2\% em início de 2013 para 38,7\% em final de 2019 (Gráfico 4). 
Gráfico 4

Relação saldo dos créditos concedidos às empresas e o PIB e participação do saldo da dívida externa nos créditos totais concedidos às empresas (em \%)

Indicadores de Endividamento das Empresas não Financeiras

60,0

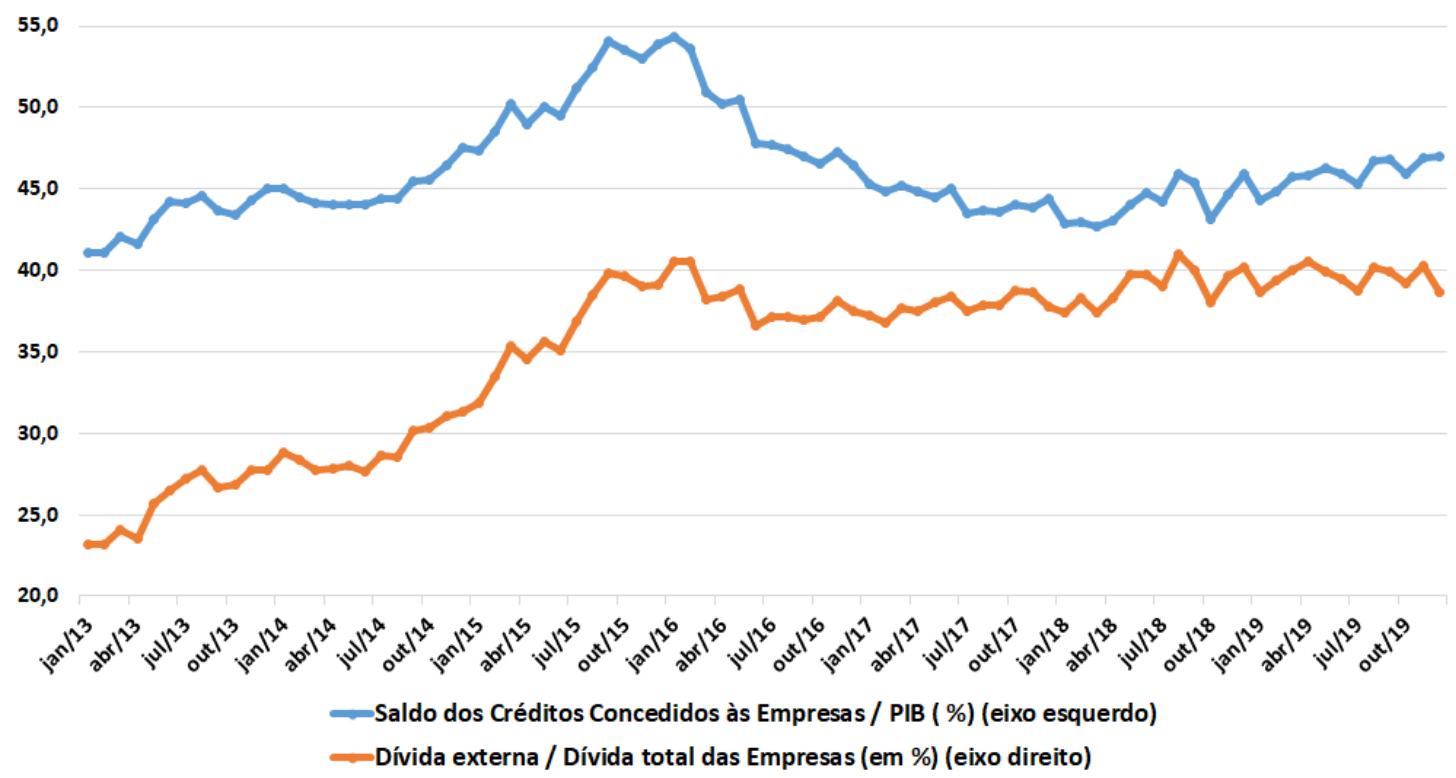

Fonte: Bacen.

As empresas são as maiores tomadoras de crédito externo. O saldo total de dívida externa das empresas foi de $\mathrm{R} \$ 1,3$ trilhão em final de 2019 e de $\mathrm{R} \$ 715$ bilhões para o governo. Em 2013, as empresas eram responsáveis por $54,6 \%$ do total da dívida externa, participação que saltou para $64,8 \%$ no final da década (Gráfico 5). Já a participação do governo na dívida externa vem se reduzindo e atingiu 34,4\% em 2019. Desse modo, o capitalismo brasileiro tornou-se cada vez mais articulado ou associado ao capital estrangeiro reproduzindo internamente seus interesses gerais a favor da desregulação e integração subordinada. 
Gráfico 5

Evolução das empresas na dívida externa total (em \%)

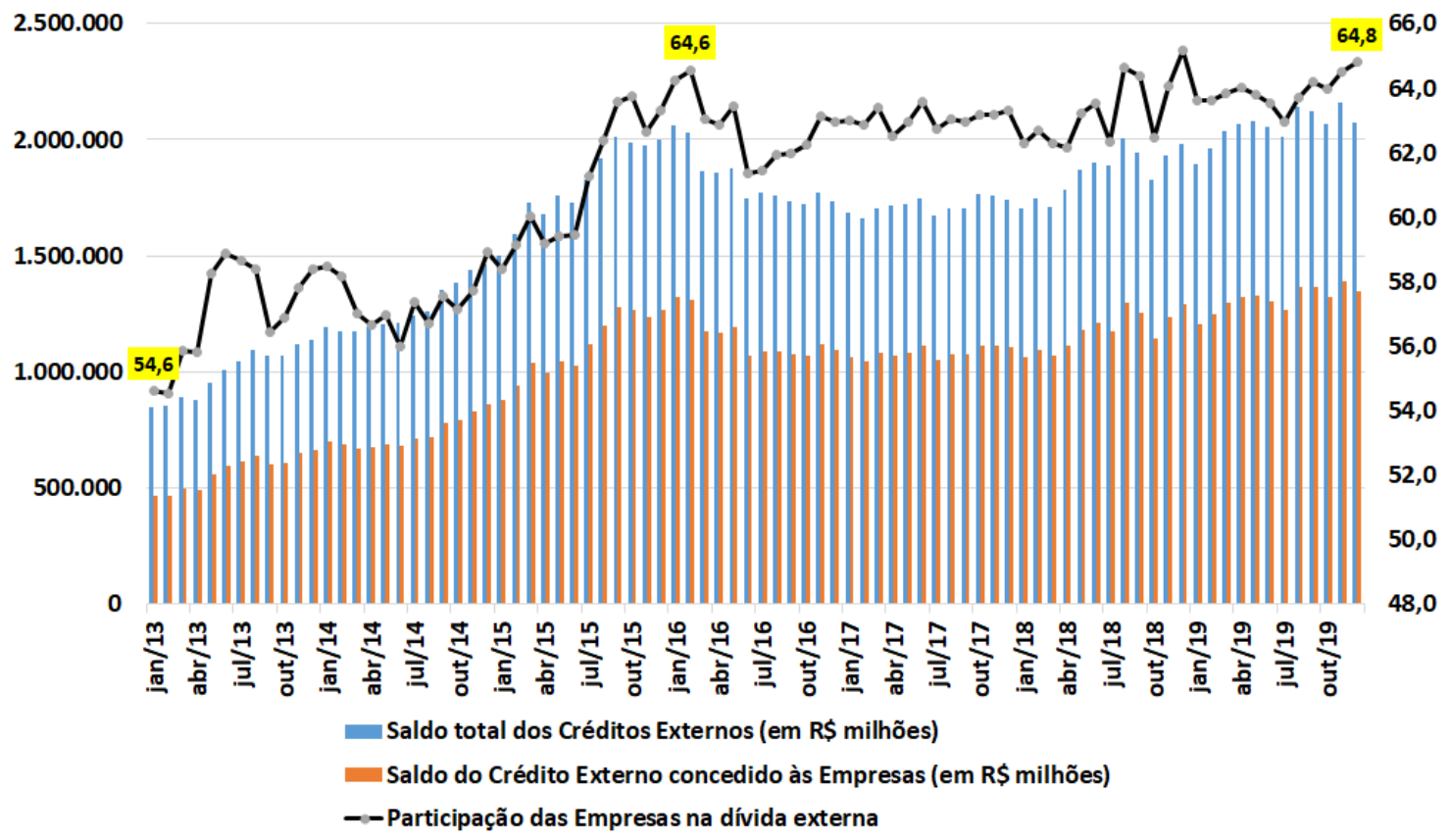

Fonte: Bacen.

Por fim, seria importante destacar que o padrão de acumulação reforçado pela maior internacionalização e desnacionalização produtiva e integrado às finanças internacionais resultou em baixa taxa de crescimento da economia e piora nas taxas de desemprego e da distribuição de renda, mas tem propiciado elevados lucros ao capital, sobretudo nos anos mais recentes, o que explica a convergência de diferentes grupos de interesse do capital. No período de 2010-2014, com taxa de crescimento acumulada de $18 \%$, o lucro acumulado dos 200 maiores grupos econômicos foi de $\mathrm{R} \$$ 809 bilhões, liderado pelos grupos financeiros e industriais. Já no período 2015-2019, marcado pela ruptura institucional e aprofundamento das reformas liberais, embora a taxa de crescimento acumulada tenha sido negativa $(-2,4 \%)$ e a taxa de desemprego incrementado fortemente, os lucros acumulados cresceram para $\mathrm{R} \$ 850$ bilhões, liderados pelos grupos financeiros e de serviços. 
Gráfico 6

200 Maiores Grupos Econômicos no Brasil: Lucro acumulado 2010-2014 e 2015-2019 (em R\$ bilhões)

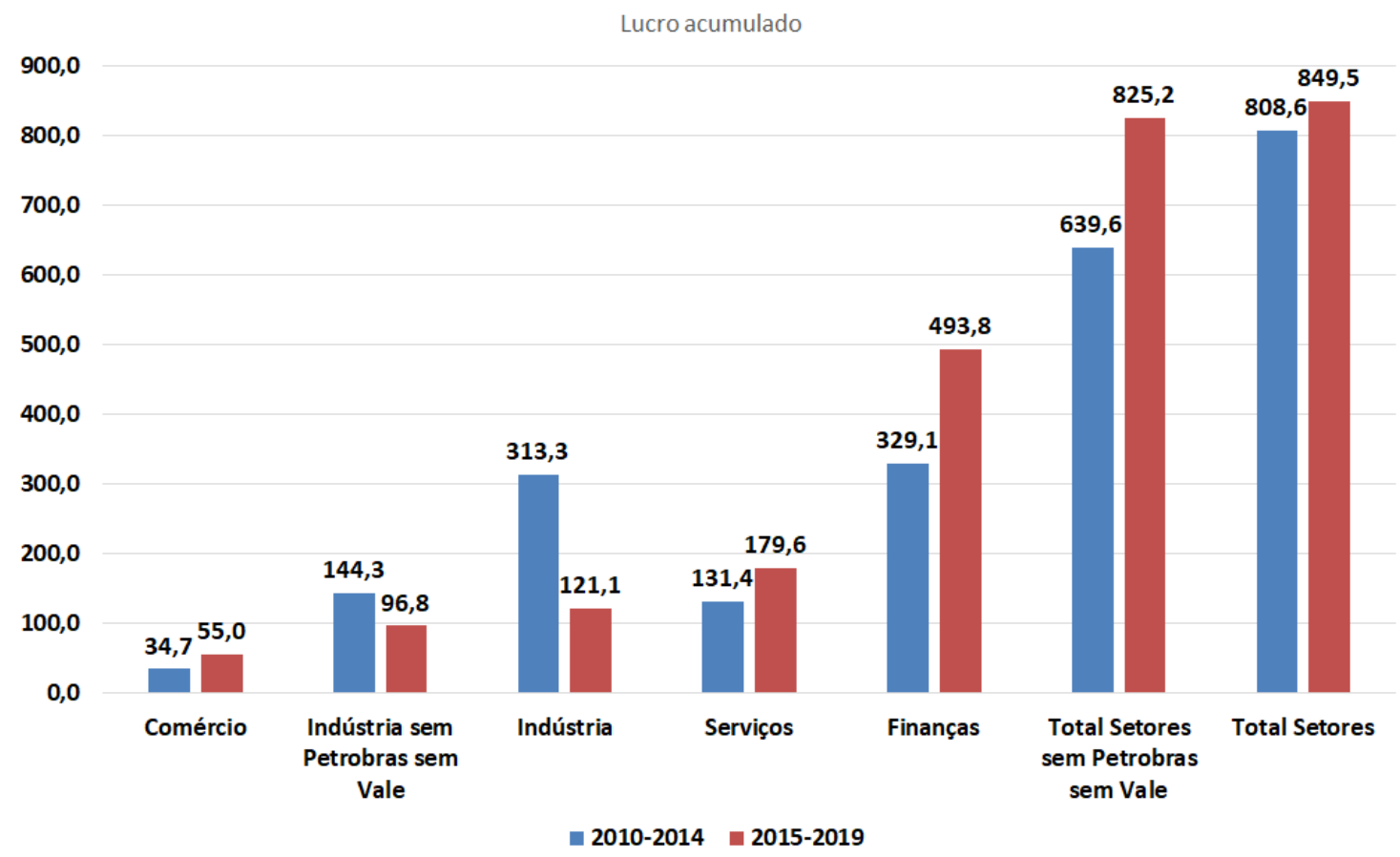

Fonte: Valor Econômico.

\section{Notas finais}

Discutimos nesse texto as transformações nas estratégias de acumulação e nas políticas econômicas na América Latina, a partir de duas proposições que emergem da análise de Wilson Cano em seu livro publicado em 1999. A primeira é a de que a 'dependência financeira externa', isto é, a subordinação da política econômica às finanças internacionais, constitui o principal divisor de águas entre o período nacional-desenvolvimentista e os períodos posteriores. Argumentou-se que em condições de escassez de divisas, em que o estoque de dívidas e ativos de curto prazo são muito elevados em relação às reservas, como ocorreu na maioria das economias do continente ao longo dos 1980s e 1990s, os governos submetem suas políticas econômicas aos interesses e às perspectivas dos países credores e dos detentores de ativos, seguindo políticas econômicas que contrariam as estratégias de um desenvolvimento produtivo e tecnológico mais abrangente e diversificado, sobretudo de atividades que não geram divisas e/ou que requerem para a sua implantação uma política econômica desenvolvimentista.

Essa circunstância mudou substancialmente no novo milênio e, por mais de uma década, os países da América do Sul e o Brasil, em particular, recuperaram o maior grau de autonomia no manejo de política econômica exatamente porque houve substancial queda na dependência financeira externa. Argumentou-se que a reversão das políticas expansionistas e distributivas ocorridas na região, mas particularmente no Brasil a partir de 2015, se deu num contexto externo bastante distinto do que se passou nos anos 1980 e 1990. Esta circunstância leva à segunda proposição deste ensaio. De forma geral, mas sobretudo no caso da economia brasileira, o abandono de políticas de desenvolvimento 
deve ser explicado por razões internas. O que a evolução das políticas econômicas praticadas na região, mas sobretudo no Brasil a partir de 2015, sugere é que a 'disciplina dos mercados', expressão eufemística da subordinação da política econômica doméstica aos interesses dos investidores financeiros, antes uma força imposta a partir das crises externas, tornou-se uma iniciativa essencialmente autoimposta por decisões políticas internas; e estas se moveram, não apenas ampliando o poder do capital sobre o trabalho, mas também subordinando as estratégias de desenvolvimento. Um dos movimentos importantes desta evolução foi o processo de desnacionalização e rearticulação dos capitais decorrente da onda de IDP ocorrida no período.

A desnacionalização e a integração financeira acabaram por unificar os interesses das distintas frações de capital na defesa tanto de uma estratégia assentada na austeridade fiscal, de forma a disciplinar o trabalho, mas também na subordinação do Estado a uma agenda de reformas prómercado, minando sua capacidade de intervenção sobre setores e atividades produtivas. Desse modo, embora existam oportunidades no cenário externo para uma retomada de um projeto nacional desenvolvimentista puxado por investimentos em infraestrutura econômica e social e em inovações, uma realidade hoje presente na economia mundial, não existe, do ponto de vista dos interesses nacionais e das ideias predominantes, vontade para que se formule e implemente políticas para tal projeto. Ao contrário, o desmonte das organizações do Estado desenvolvimentista, do que sobrou dele, e a consolidação do neoliberalismo e de uma estratégia nacional 'passiva e subordinada' de integração é o projeto que tem prevalecido.

\section{Referências bibliográficas}

ABELES, Martin; CHERKASKY, Marín. Revising balance of payments constrained growth 70 years after ECLAC's Manifesto: The case of South America. Revista de Economia Contemporânea, v. 24, n. 1, p. 1-24, 2020.

ÁLVAREZ, Ramiro Eugenio. Essays on the Argentine political economy through the lens of the classical Keynesian approach. Tese (Doutorado)-Siena, Italia, 2020.

AMSDEN, Alice. Escape from empire. Cambridge, Mass.: The MIT Press, 2007.

BACEN. Relatório do Investimento Direto. Brasília: Banco Central, 2020.

BASTOS, Carlos Pinkusfeld; AIDAR, Gabriel. Brazil's economy: recent trends and perspectives. Rio de Janeiro: UFRJ. Instituto de Economia, 2019. (Texto para Discussão, n. 015).

BRESSER-PEREIRA, L. C. Reflecting on new developmentalism and classical developmentalism. Review of Keynesian Economics, 2016.

CAMPELLO, Daniela. The politics of market discipline in Latin America. New York: Cambridge University Press, 2015.

CANO, Wilson. Soberania e política econômica na América Latina. São Paulo: UNESP, 1999.

CANO, Wilson. Uma agenda nacional para o desenvolvimento. Revista Tempo do Mundo, Brasília, IPEA, v. 2, n. 2, p 7-41, 2010.

ECLAC. Capital flows to Latin America and Caribbean. Washington Office: ECLAC, 2020. 
FRENKEL, Roberto; RAPETTI, Martin. External fragility or deindustrialization: what is the main threat to Latin American countries in the 2010s? World Economic Review, v. 1, p. 37-57, 2012.

FRIEDEN, Jeffry A. Currency politics, the political economy of exchange rate policy. Princeton e Oxford: Princeton University Press, 2015.

FURTADO, Celso. A nova dependência, dívida externa e monetarismo. São Paulo: Paz e Terra, 1982.

GUILLÉN, Arturo. El régimen de acumulación en México: caracterización, tendencias y propuestas para su transformación. Serie Estudios y Perspectivas - Sede Subregional de la CEPAL en México, n. 190 (LC/TS.2021/42; LC/MEX/TS.2021/7). Ciudad de México: Comisión Económica para América Latina y el Caribe (CEPAL), 2021.

HEIN, Eckhard. Finance-dominated capitalism and redistribution of income: a Kaleckian perspective. Levy Economics Institute, 2013. (WP, n. 746).

HIRATUKA, Célio; SARTI, Fernando. Considerações sobre o potencial de complementaridade produtiva na América do Sul. Cepal/IPEA, 2021. Relatório de pesquisa.

HIRATUKA, Celio; SARTI, Fernando. Transformações na estrutura produtiva global, desindustrialização e desenvolvimento industrial no Brasil: uma contribuição ao debate. Campinas: Unicamp. IE, 2015. (Texto para Discussão, n. 255).

JESSOP, Bob. State theory: putting the capitalist state in its place. London: Polity Press in association with Basil Blackwell, 1990.

KALECKI, M. Political aspects of full employment. Political Quarterly, v. 14, n. 4, 1943.

KALTENBRUNNER, Annina; PAINCEIRA, Juan P. Financierización en América Latina: implicâncias de la integración financieira subordinada. In: ABELES, Martín; CALDENTEY, Esteban P.; VALDECANTOS, Sebastián. Estudio sobre financierización em América Latina. Buenos Aires: CEPAL, 2018.

KOTZ, David M. The rise and fall of neoliberal capitalism. Cambridge, MA: Harvard University Press, 2015.

MADDISON Project Database (MPD) 2020.

MEDEIROS, Carlos Aguiar de. A economia brasileira no novo milênio: continuidade e mudanças nas estratégias de desenvolvimento. Economia Contemporânea, Número Especial, p. 1-16, 2017.

MEDEIROS, Carlos Aguiar de. Financial dependency and growth cycles in Latin American countries. Journal of Post Keynesian Economics, v. 3, n. 1, p. 79-100, 2008.

MEDEIROS, Carlos Aguiar de; SARTI, Fernando. A internacionalização da produção e os desafios ao desenvolvimento econômico. Cadernos do Desenvolvimento, Rio de Janeiro, v. 15, n. 26, p. 259276, 2020.

MEDEIROS, Carlos A.; TREBAT, Nicholas. The failures of neoliberalism in Brazil. Journal of Economic Issues, v. LV, n. 2, p. 423-430, Jun. 2021. 
MORTON, Adam David. Unravelling Gramsci. London: Pluto Press, 2007.

O’DONNELL, Guillermo. Estado y alianzas en la Argentina, 1956-1976. Desarrollo Económico, v. 16, n. 64, p. 523-554, 1977.

PREBISCH, Raul. O desenvolvimento econômico da América Latina e alguns dos seus principais problemas. Escrito em 1949, como introdução ao Estudio económico de la América Latina, 1948 (E/CN. 12/89), e posteriormente publicado in CEPAL, Boletín económico de América Latina, v. VII, n. 1, Santiago do Chile, 1962. Publicação da Organização das Nações Unidas, n. de venda: 62.II.G.I., 1949.

RODRÍGUEZ, Octavio. O estruturalismo Latino-Americano. Rio de Janeiro: Civilização Brasileira, 2009.

SARTI, Fernando; LAPLANE, Mariano. Internacionalização, desnacionalização e desenvolvimento. Observatório da Economia Contemporânea. Le Monde Diplomatique, 2019.

SARTI, Fernando; LAPLANE, Mariano. Internacionalização produtiva, competitividade e desenvolvimento. In: SARTI, F.; DIEGUES, A. C. (Coord.). Brasil: indústria e desenvolvimento em um cenário de transformação do paradigma tecno-produtivo. Campinas: Instituto de EconomiaUnicamp, 2021.

SERRANO, Franklin; SUMMA, Ricardo. Conflito distributivo e o fim da breve era de ouro da economia brasileira. Novos Estudos CEBRAP, v. 37, n. 2, p. 175-189, 2018.

SERRANO, Franklin; SUMMA, Ricardo. Aggregate demand and the slowdown of Brazilian economic growth in 2011-2014. Nova Economia, v. 25, p. 803-833, 2015.

TAVARES, Maria da Conceição. Da substituição de importações ao capitalismo financeiro: ensaios sobre a economia brasileira. Rio de Janeiro: Ed. Zahar, 1972.

UNCTAD. Division on Investment and Enterprise. World Investment Report, Statistical Annex. Disponível em: http://unctad.org/en/Pages/DIAE/World\%20Investment\%20Report/World_Investment_Report.aspx.

VALOR ECONÔMICO. 200 Maiores Grandes Grupos, ano 19, n. 19, dez. 2020. 